DOI: 10.46340/ephd.2021.7.4.3

Liubomyr Dudarchuk

ORCID ID: https://orcid.org/0000-0002-6861-5955

Lesya Ukrainka National University of Volyn, Lutsk, Ukraine

\title{
CULTURAL PROCESSES IN PROSKURIV DURING THE NAZI OCCUPATION (1941-1944)
}

\author{
Любомир Дударчук \\ Волинський національний університет імені Лесі Українки, Луцьк, Україна
}

\section{КУЛЬТУРНІ ПРОЦЕСИ У ПРОСКУРОВІ В ПЕРІОД НАЦИСТСЬКОЇ ОКУПАЦІї (1941-1944 PР.)}

The article analyzes the cultural processes that took place in Podillya, in particular in Proskuriv (now Khmelnytskyi) during the Nazi occupation. Attention is paid to the activity of the regional museum after the establishment of the occupying power in the region. It is proved that this institution suffered significant material damage at the initial stage of the German-Soviet war, and after the re-establishment, it was planned to be used for the purpose of ideological influence on the local population. The filling of the exposition halls of the museum is characterized. It is established that the museum's exposition contained many valuable things: samples of weapons, ceramics, ancient utensils, paintings, etc.

It is proved that the drama theater was an important center of the cultural life of the town in the studied period of time. The cast of the institution is analyzed, as well as the requirements of the occupation authorities for hiring artists. The problems that existed in the field of dramatic art are outlined. Attention is paid to the repertoire of the theater, it is shown how the conditions of the war have affected its content. The activity of the local authorities aimed at the development of Proskuriv's theatrical life is studied. The functioning of the puppet theater in the town is described. The activity of the town's library as an important center of intellectual and cultural life is covered. The conditions for using its services are established. It is proved that the literature stored in the book collection was subjected to strict censorship. A number of problems that negatively affected the library's activities have been analyzed (first of all, the strict control by the Nazi administration and improper attitude of readers to their responsibilities). Attention is paid to the distribution of print media in the occupied territory. It has been established that "The Ukrainian Voice" newspaper was published in Proskuriv during the given period. The informational content of the periodical is analyzed. It is proven that many articles published in the newspaper were definitely anti-Soviet and anti-Semitic and were used for propaganda purposes.

Keywords: culture, museum, library, press, theater, Nazi occupation, Proskuriv.

Період 1941-1944 pp. на Поділлі характеризувався значними змінами суспільного життя. Безумовно, в цей час регіон зазнав значних людських та матеріальних втрат. Важливим, але недостатньо вивченим аспектом окупаційного режиму на вказаній території $\epsilon$ перебіг культурних процесів. В багатьох працях, присвячених даній проблемі, основна увага звертається на збитки, заподіяні музеям, театрам, бібліотекам у роки Другої світової війни. Натомість функціонування цих установ в 1941-1944 pр. зазвичай залишається поза увагою істориків. Окрім того, наше дослідження, з огляду на його локальний характер, буде корисним при вивченні особливостей окупаційного режиму в окремих населених пунктах України. Це й зумовлює актуальність даної статті.

Мета дослідження - проаналізувати перебіг культурних процесів у Проскурові в роки німецько-радянської війни.

Задля досягнення мети ставимо перед собою низку завдань:

1. Простежити функціонування краєзнавчого музею; 
2. Звернути увагу на розвиток драматичного мистецтва;

3. Висвітлити діяльність міської бібліотеки;

4. Проаналізувати поширення преси на вказаній території.

Аналіз останніх досліджень і публікацій. Окремі аспекти задекларованої проблема були предметом вивчення дослідників. Зокрема, Ю. Олійник та О. Завальнюк охарактеризували соціальноекономічне та культурно-освітне життя на території генеральної округи «Волинь-Поділля» в 19411944 pp. ${ }^{1}$. У своїй дисертації В. Фульмес проаналізував поширення преси на окупованій території ${ }^{2}$. Б. Чернов звернув увагу на мотиви представників окупаційної адміністрації, якими вони керувалися, дозволяючи друк значної кількості газет на теренах райхкомісаріату «Україна» ${ }^{3}$.

Виклад основного матеріалу. Після окупації України Хмельниччина увійшла до складу генеральної округи «Волинь-Поділля». Культурне життя регіону в цей час, зазвичай, зосереджувалося в містах - Кам'янці-Подільському, Шепетівці, Дунаївцях та інших. До цього списку варто віднести і Проскурів (нині - м. Хмельницький).

Важливим культурним осередком міста в окреслений період був краєзнавчий музей. У кінці вересня 1941 р. на шпальтах газети «Український голос» вийшла друком стаття його директора Романіва ${ }^{4}$, в якій повідомлялося про реорганізацію закладу. Автор стверджував, що під час відступу більшовиків внаслідок пограбування з музею зникло чимало цінних експонатів, зокрема, кишеньковий годинник часів французько-російської війни 1812 р. з емальованими портретами Наполеона та Олександра I. Тоді ж було знищено старовинний годинник з білого мармуру (згодом відшукали лише його фрагменти), втрачено зразки старовинної зброї - дуельні пістолети німецького виробництва та чимало цінних речей - звукову кіноапаратуру, мікроскоп та ін. Незважаючи на це, в майбутньому керівництво музею мало намір провадити в закладі масштабну діяльність - передбачалося відкриття трьох відділів (природничого, археологічно-палеонтологічного та мистецького), наповнених експонатами місцевого походження, що сприяло б всебічному вивченню регіону - його історії, геології, фауни і т. д. Окрім експозиційних залів планувалося урухомлення бібліотеки т. зв. «закритого типу»користуватися іiі послугами було б дозволено лише в стінах музею5. Отже, на початковому етапі німецько-радянської війни цей заклад зазнав значних матеріальних втрат, що ускладнювало його діяльність. Незважаючи на це, після відкриття він мав стати не лише культурною інституцією, а й мав значні можливості для перетворення у науковий осередок.

Дещо згодом, у липні 1942 р., на сторінках міської преси повідомлялося, що відкриття Проскурівського краєзнавчого музею, імовірно, відбудеться незабаром. Станом на цей час у закладі знаходилося чимало цінних артефактів - старовинна зброя, кераміка, давній посуд, порцеляна, картини і т.п. У природничому відділі експонувалися цікаві зразки місцевої фауни. Тоді ж директор висловлював сподівання на те, що музейні колекції будуть поповнюватися в майбутньому. Однак, найбільш цікавий фрагмент статті присвячений аналізу діяльності закладу в 1939-1941 pp. На думку автора, в цей час функціонування музею мало низку негативних рис: 1) окрім справді цінних предметів відвідувачам презентували муляжі (принаймні, частина 3 яких була фальсифікаціями), на стінах закладу знаходилося чимало наочності - малюнків та цитат. Тому після встановлення нацистської окупаційної адміністрації багато речей прибрали, залишивши лише автентичні експонати; 2) робота наукових співробітників виконувалася на низькому фаховому рівні, свідченням чого була значна кількість музейних предметів, не облікованих належним чином. Керівництво визнавало, що для вирішення даної проблеми необхідно запросити спеціалістів з інших культурних установ, однак труднощі зі сполученням це унеможливили. Варто зазначити, що в аналізованій статті фіксуємо прояви антисемітизму - автор, на наш погляд, не випадково зауважує, що в час існування у місті радянської влади переважна більшість наукових співробітників музею були «жидами» ${ }^{6}$ Погоджуючись із низкою висловлених зауваг, варто наголосити на двох моментах: по-перше,

\footnotetext{
${ }^{1}$ Олійник, Ю. Завальнюк, О. (2012). Нацистський окупаційний режим в генеральній окрузі «Волинь-Поділля» (1941-1944 рр.). Хмельницький: Поліграфіст-2, 320.

${ }^{2}$ Фульмес, В. С. (2021). Церковно-релігійна і громадська діяльність митрополита Анатолія Дублянського. (Дисертація доктора філософії). Волинський національний університет, Луцьк, Україна, 270.

3 Чернов, Б. (2006). Окупаційна преса Райхскомісаріату Україна: розбудова і функціонування (1941-1943 pр.). Наукові записки Інституту політичних і етнонаціональних досліджень ім. І.Ф. Кураса НАН Украӥни, 31, 51-68.

${ }^{4}$ Тут і далі по тексту, де вказано лише прізвище, ініціали в джерелі відсутні.

5 Український голос (1941). Міський музей, 30 вересня, 4.

${ }^{6}$ Український голос (1942). Проскурівський музей антисоветської культури, 23 липня, 4.
} 
експоновані у музеях речі не обов'язково мають бути автентичними, використання муляжів, копій, таблиць допускається за умови, що вони не є фальсифікаціями; по-друге, в роки нацистської окупації музеї, як і в СРСР, часто використовувались з пропагандистською метою (про що свідчить назва аналізованої статті) ${ }^{1}$.

В досліджуваний період на Хмельниччині значного поширення набуло драматичне мистецтво. Одним із його важливих осередків залишався театр у Проскурові. Вже у жовтні 1941 р. на шпальтах газети «Український голос» повідомлялося про пошук акторів для працевлаштування в закладі. Бажаючі обійняти відповідні посади: а) мали бути українцями; б) зобов'язувалися вивчити напам'ять один віршований і прозовий твір; в) могли бути як професіоналами, так і аматорами. Відбір запланували на другу половину жовтня - 317 до 21 числа в приміщенні театру. Бажаючі могли отримати додаткову інформацію в директора закладу або його художнього керівника ${ }^{2}$. Тобто, на початковому етапі окупаційного періоду зусилля місцевої влади спрямовувалися на вирішення кадрових питань - забезпечення театру достатньою кількістю фахових працівників.

Зауважимо, що вже 19 жовтня о 15 год. заклад мав розпочати свою роботу масштабним концертом українських народних пісень та постановкою С. Васильченка «На перші гулі» ${ }^{3}$. Відбувалися в театрі концерти і за участі військового оркестру - один із таких анонсувався у міській пресі восени 1941 р. Його музичний супровід мав забезпечувати оркестр 301-го батальйону ляндшуців. Відвідати дану імпрезу міг будь-хто з місцевих українців, придбавши квиток, ціна за який становила від одного до п’яти карбованців. Передбачалося, що програма заходу складатиметься із різноманітних композицій - маршів, вальсів, українських народних пісень, соло на скрипці і акордеоні та інших ${ }^{4}$. Наявність у місті військових концертів у досліджуваний період зумовлювалася перебуванням там солдатів та офіцерів Вермахту, для яких такі заходи були одним зі способів проведення дозвілля.

Зауважимо, що професійний рівень акторів Проскурівського театру був різний. Зокрема, М. Мельничук, аналізуючи у своїй статті постановку П. Мирного «Лимерівна», яка відбулась на сцені закладу, стверджував, що артисткою Басістою (виконувала роль головної героїні) в одному епізоді «... замість життєвих переживань більше відтворено сварку». Негативною стороною у виступі їі колеги дописувач вважав погану дикцію. Однак багато працівників театру в цій постановці свої ролі зіграли добре. Зокрема, з відчуттям «радісного хвилювання»автор сприйняв гру Моргунової, Тхоржевського, Ячміня, Тація та інших. Окрім цього, кілька критичних зауваг у публікації висловлено на адресу дирекції закладу - згідно зі словами М. Мельничука, під час імпрези трапилася плутанина з квитками, деякі глядачі дивилися виставу стоячи, частина відвідувачів порушувала дисципліну. 3 метою уникнення подібних ситуацій у майбутньому автор рекомендував: по-перше, подбати про те, щоб глядачі займали свої місця відповідно до куплених квитків, а, по-друге, мати в залі працівника, який би стежив за порядком під час заходів ${ }^{5}$. Цікаво, що після вміщеної рецензії редакція газети нагадувала про необхідність грати на сцені не побутові п’єси, а твори патріотичного змісту ${ }^{6}$. Останній факт є виразним свідченням того, що принаймні частина проскурівчан розглядала драматичне мистецтво не лише як одну з форм культурного дозвілля, а й як важливий засіб формування почуття національної самосвідомості у місцевих жителів. Вміщення ж статей з численними критичними заувагами дозволяло акторам удосконалювати свій професійний рівень.

У кінці 1941 р. театр збагатив свій репертуар новими водевілями та народними танцями. Тоді ж колектив закладу працював над постановкою I. Карпенка-Карого «Мартин Боруля» та новорічною імпрезою, програма якої складалася з виступу капели бандуристів, художнього читання, танців, пісенних композицій та ін. ${ }^{7}$ Однак рівень матеріально-технічного забезпечення закладу лишався незадовільним - існували проблеми з оформленням декорацій, відчувався брак українських національних костюмів ${ }^{8}$, що, ймовірно, негативно впливало на якість постановок.

\footnotetext{
${ }^{1}$ Стаття називалася «Проскурівський музей антисовєтської культури».

2 Український голос (1941). Конкурс артистів, 12 жовтня, 6.

${ }^{3}$ Український голос (1941). В театрі, 19 жовтня, 5.

${ }^{4}$ Український голос (1941). Військовий концерт, 26 жовтня, 6.

5 Український голос (1941). «Лимерівна» у постановці міського драматичного театру, 3 грудня, 4.

6 Український голос (1941). Від редакиї̈, 3 грудня, 4.

7 Український голос (1941). Творча прачя, 18 грудня, 4.

8 Український голос (1941). Украӥнський конщерт, 21 грудня, 3.
} 
Драматичне мистецтво Проскурова не залишалося поза увагою місцевої влади. Про це свідчить нарада керівництва театру, яка відбулася 17 січня 1942 р. в присутності голови міської управи Ліщинського. Ї̈̈ учасники звернули увагу на низку негативних моментів у діяльності закладу застарілість репертуару, відсутність тематичної спрямованості концертів, нагадали про необхідність підвищувати професійний рівень акторів. Тоді ж були висловлені пропозиції щодо організації хору, підготовки заходів, приурочених до відзначення річниці Дня соборності України та бою під Крутами, а також утворення Художньої ради, до складу якої мало увійти не лише керівництво закладу, а й представники громадських організацій. Режисери театру визнали слушність висловлених зауваг та пообіцяли врахувати їх під час майбутньої діяльності театру ${ }^{1}$. Як бачимо, громадськість пропонувала конкретні кроки, спрямовані на розвиток драматичного мистецтва у місті.

Ймовірно, для того, аби втілити в життя вказані рекомендації, невдовзі дирекція повідомляла про набір до закладу професійних акторів і хористів (басів, сопрано, альтів, тенорів) та скуповувала килими, перуки, посуд, історичну зброю та українські костюми ${ }^{2}$. Можливість театру за ці речі заплатити свідчить, на наш погляд, про непоганий рівень його фінансового забезпечення. Згодом, у лютому 1942 р., у закладі відбулися кадрові зміни - призначено нового директора, деяких малокваліфікованих працівників звільнено. Тоді ж колектив розпочав роботу над п’єсою «Назар Стодоля» та постановкою патріотичного змісту 3 промовистою назвою «В Україні сліз не стало».

Важлива інформація про використання окупаційною адміністрацією драматичного мистецтва у своїх цілях міститься в «Українському голосі» від 14 травня 1942 р. Тоді в рубриці «Театральна хроніка» був опублікований короткий аналіз комедії П. Куліша «Мина Мазайло», зіграної у міському театрі на початку місяця. В огляді наголошувалося на актуальності твору, майстерній грі акторів (за незначним винятком), приємному враженні глядачів від перегляду постановки. Однак, на завершення дописувач повідомив цікаву деталь - кінець п'єси було змінено - в останній сцені з'явився енкаведист, який арештував Мокія (такий епізод відсутній в авторському тексті). Це робилося для того, аби продемонструвати, яка доля чекала українців з високим рівнем національної самосвідомості, навіть, якщо вони «збирались до комсомолу» ${ }^{4}$. Аналізована ситуація свідчить про те, що театральне мистецтво Проскурова у досліджуваний період активно використовувалось 3 метою антирадянської пропаганди. Саме тому часто на сцені ставили твори, які пройшли сувору цензуру, а інколи вдавалися до зміни і спотворення їхнього змісту.

У кінці жовтня 1942 р. Проскурівський театр відзначив першу річницю своєї діяльності. Урочистості з цієї нагоди почалися виступом його директора Мацюка, який окреслив завдання закладу в культурній сфері, висловив сподівання на те, що театр і жителі міста будуть спільно працювати «... на славу своїй батьківщині». Згодом на сцені було зіграно спектакль. Заходи відбувалися і наступного дня, коли для школярів, педагогів, а також представників відділу освіти та культури актори поставили п’єсу «Ой, Морозе, Морозенку». Тоді ж вирішено у майбутньому щовівторка грати спектаклі для школярів, а також зібрано грошову допомогу для бідних ${ }^{5}$. Як бачимо, після першої річниці своєї діяльності Проскурівський театр користувався значною популярністю в середовищі місцевих жителів i, що дуже важливо, в умовах воєнного лихоліття долучався до благодійницьких проектів, аби в такий спосіб покращити матеріальне становище малозабезпечених містян.

На початку листопада 1942 р. на сторінках «Українського голосу» дирекція закладу інформувала, що з огляду на небезпеку поширення тифу відвідування глядачами імпрез припиняється. Однак, незважаючи на це, колектив продовжив працювати - тривала підготовка постановок «Циганка Аза», «Ніч під Івана Купала», «Його секретарка», а також концерту для військових ${ }^{6}$. Перерва в роботі театру, імовірно, тривала кілька місяців - вже у лютому 1943 р. в газеті «Український голос» вийшов огляд п’єси «Ой, не ходи, Грицю», поставленій на його сцені 7 .

\footnotetext{
${ }^{1}$ Український голос (1942). Нарада в справі міського театру, 22 січня, 4.

2 Український голос (1942). Видання від 25 січня, 4.

${ }^{3}$ Український голос (1942). Реорганізація міського театру, 19 лютого, 4.

${ }^{4}$ Український голос (1942). Театральна хроніка, 14 травня, 4.

5 Український голос (1942). Перша роковина Проскурівського драматичного театру, 25 жовтня, 4.

6 Український голос (1942). Оголошення, 8 листопада, 4.

7 Український голос (1943). «Ой, не ходи, Грицฺю, та й на вечорниці» (В постановиі Проскурівського

драматичного украӥнського театру), 4 лютого, 4.
} 
У кінці червня 1943 р. згаданий часопис повідомляв про організацію в місті лялькового театру. У статті наголошувалося на тому, що заклад є окремою культурною інституцією ${ }^{1}$. Невдовзі у міській пресі була надрукована стаття з оглядом п’єси «Чарівна галоша», постановка якої відбулася на його сцені. Автор відзначав вдалий вибір твору з огляду на наявність у ньому багатьох виховних моментів. Незважаючи на невелику кількість акторів (близько десяти осіб), колективу вдалося справити на дописувача приємне враження. Неабияку роль у цьому відіграло гарне художнє оформлення. Тоді ж повідомлялося, що працівники закладу розпочали підготовку постановки «Халіф і бузько». Про високопрофесійну гру акторів, на наш погляд, свідчить і те, що вони влітку 1943 р. виїхали на гастролі до Німеччини, де мали забезпечувати дозвілля українських остарбайтерів ${ }^{2}$. Таким чином, можемо констатувати, що ляльковий театр в умовах нацистської окупації, будучи одним із важливих центрів культурного життя у місті, створював конкуренцію міському драматичному театру.

Окрім згаданих мистецьких закладів, важливим осередком інтелектуального життя Проскурова в окреслений період була міська бібліотека. Нам не вдалося встановити точну дату початку ії роботи, однак відомо, що в останній декаді листопада 1941 р. там уже було урухомлено кілька відділів технічної літератури, літературознавства і критики, художньої літератури (російською мовою) та аналогічний відділ україномовних видань. 3 огляду на те, що в той час закладу ще не було присвоєне iм'я ${ }^{3}$, можна припустити, що книгозбірня розпочала свою діяльність незадовго до цього. Тоді ж «Український голос» повідомляв про перевірку, за підсумками якої з бібліотеки вилучили книги виразно прорадянського змісту, i ті, які, на думку комісії, були «... без усякої вартости і змісту». Крім цього, відібрали книги (по чотири примірники), доступ до яких мало обмежене коло читачів. Решту видань залишили для загального користування. При цьому, від бібліотекарів вимагалось повирізати 3 них портрети більшовицьких діячів, присвяти, адресовані ним та передмови з позитивним зображенням комунізму ${ }^{4}$ Відтак, можемо констатувати, що функціонування міської книгозбірні перебувало під пильним контролем окупаційної адміністрації, яка вилучала з ії фондів літературу прорадянського змісту, а ту, яка лишалася, піддавала суворій цензурі.

Історичні джерела, датовані березнем 1942 р., свідчать, що в цей час бібліотека знаходилась на вулиці Олександрівській і працювала щоденно з 11 до 19 год., однак видача літератури здійснювалася 312 до 19 год. (окрім неділі). Для користування її послугами читачі зобов'язувалися сплатити вступний внесок у розмірі десяти карбованців та в подальшому щомісяця вносити половину цієї суми. Запис здійснювався після пред'явлення паспорта. За несвоєчасне повернення книг передбачався штраф у розмірі одного карбованця 5 . (Зауважимо, що О. Завальнюк та Ю. Олійник стверджують, що його розмір становив три карбованці $\left.{ }^{6}\right)$. Варто зазначити, що євреям користуватися послугами книгозбірні заборонялося ${ }^{7}$. Останній факт був одним із проявів дискримінації населення на окупованих територіях за його етнічною приналежністю.

Бібліотека в досліджуваний період мала низку проблем, зумовлених неналежним ставленням читачів до своїх обов'язків - впродовж зими ${ }^{8}$, літа ${ }^{9}$, осені $^{10} 1943$ р. у проскурівській пресі з'являлись оголошення з вимогою до боржників повернути випозичену літературу (у разі невиконання прохання останніх погрожували притягнути до судової відповідальності, вжити щодо них «... відповідні адміністративні заходи»). Відтак, можемо припустити, що це негативно впливало на роботу книгозбірні.

Невід'ємною частиною культурних процесів загалом і повсякдення зокрема на окупованій території були друковані засоби масової інформації. На підконтрольній нацистській адміністрації теренах було дозволено поширення значної кількості преси, яка були важливим засобом пропаганди

\footnotetext{
${ }^{1}$ Український голос (1943). Ляльковий театр у Проскурові, 27 червня, 4.

2 Український голос (1942). «Чарівна галоша» в постановиі Проскурівського лялькового театру, 1 серпня, 4.

${ }^{3}$ Український голос (1942). Колектив бібліотеки пропонував присвоїти їй ім'я Івана Нечуя-Левицького, щчо й було зроблено, 8 березня, 4.

${ }^{4}$ Український голос (1941). Міська бібліотека, 23 листопада, 3.

5 Український голос (1942). Видання від 8 березня, 4.

${ }^{6}$ Олійник, Ю. Завальнюк, О. (2012). Нацистський окупаиійний режим в генеральній окрузі «Волинь-Поділля»

(1941-1944 рр.). Хмельницький: Поліграфіст-2, 155.

${ }^{7}$ Український голос (1942). Видання від 8 березня, 4.

8 Український голос (1943). До читачів Проскурівської міської бібліотеки, 21 лютого, 4.

${ }^{9}$ Там само.

10 Український голос (1942). Оголошення, 21 жовтня, 4.
} 
в середовищі місцевого населення. Зокрема, в одній із директив політуправління райхкомісаріату «Україна» наголошувалося на тому, що ці газети «... не слугують народним чи культурним потребам населення чи навіть віровизнанням... Кожен рядок повинен допомагати у здійсненні великої місії фюрера у створенні нової Свропи» ${ }^{1}$. При цьому варто зазначити, що становище легальної преси в Україні впродовж 1941-1944 pp. зазнавало змін. Зокрема, А. Жив'юк доцільно поділяе іiі функціонування на два періоди - відносно безцензурний (кінець літа - початок осені 1941 р. до весни 1942 р.) та час, коли видання перебували під повним контролем представників нацистської влади (3 весни 1942 р. до початку 1944 р.) $)^{2}$. Дана класифікація, на наш погляд, може бути застосована до газети «Український голос», що виходила друком у Проскурові.

Редактором даного видання був О. Кравчук, відповідальним редактором - М. Ліщинський³. Автором опрацьовані номери, які хронологічно охоплюють період із кінця вересня 1941 р. до грудня 1943 р. Періодичність виходу газети становила двічі на тиждень - у четвер та неділю, обсяг - від чотирьох до шести сторінок. На шпальтах «Українського голосу» містилися дописи різноманітного змісту - дані про перебіг воєнних дій, огляд тогочасної політичної ситуації в світі, статті антирадянського та антисемітського спрямування, повідомлення про культурно-релігійне та соціально-економічне життя на території райхкомісаріату «Україна», розпорядження окупаційної адміністрації, які регулювали різноманітні сфери життя округи. Окремий тематичний блок становлять дописи, присвячені проблемі остарбайтерів - заклики зголошуватись на роботу до Німеччини, показ життя тамтешніх працівників зі Сходу. Ці статті мали виразно пропагандистське спрямування. Зауважимо, що чимало статей, надрукованих у виданні, були суворо цензурованими, відтак висвітлювали події дуже тенденційно. Однак для істориків дана газета $\epsilon$ цінним історичним джерелом, адже містить важливу фактичну інформацію, яка дозволяє вивчати особливості окупаційного режиму в окремих регіонах та населених пунктах.

Висновки. Таким чином, можемо підсумувати, що впродовж 1941-1944 рр. Проскурів залишався важливим центром культурного життя на Поділлі. В цей час у місті діяв театр, репертуар якого був дуже широким - від творів української класики до концертів та постановок побутового змісту. Незважаючи на те, що у закладі працювали (окрім фахових акторів) аматори, їхній професійний рівень був досить високий. Працівники театру займалися не лише мистецькою, а й благодійницькою діяльністю. Однак, у функціонуванні закладу була низка негативних рис: брак костюмів для вистав та незадовільне оформлення декорацій. 3 метою антирадянської пропаганди окупаційна адміністрація вдавалася до викривлення змісту постановок. 3 літа 1943 р. ще одним осередком драматичного мистецтва у Проскурові став ляльковий театр. На початковому етапі німецько-радянської війни значних матеріальних втрат зазнав краєзнавчий музей. Незважаючи на це, впродовж 1941-1942 pр. місцевою владою докладено значних зусиль для відновлення його діяльності.

Важливим осередком інтелектуального життя міста в досліджуваний період була бібліотека. Маючи у своєму складі низку відділів (технічної літератури, літературознавства і критики, художньої літератури українською та російською мовами), вона розгорнула активну діяльність. Однак, негативно на функціонуванні книгозбірні позначилася цензура з боку нацистської влади, внаслідок якої значну кількість книг було вилучено, а також недобросовісне ставлення читачів до своїх обов'язків. В період нацистської окупації у Проскурові виходила друком газета «Український голос», на шпальтах якої містилася інформація про суспільно-політичні процеси як загальноєвропейського, так і регіонального/місцевого рівня.

\section{References:}

1. Ukrainskyi holos [Ukrainian Voice] (1941). V teatri, 19 zhovtnia [In the theatre, October, 19], 5. [in Ukrainian].

2. Ukrainskyi holos [Ukrainian Voice] (1941). Vid redaktsii, 3 hrudnia [Editors` note, December, 03], 4. [in Ukrainian].

3. Ukrainskyi holos [Ukrainian Voice] (1941). Viiskovyi kontsert, 26 zhovtnia [Military Concert, October, 26], 6. [in Ukrainian].

\footnotetext{
1 Чернов, Б. (2006). Окупаційна преса Райхскомісаріату Україна: розбудова і функціонування (1941-1943рр.). Наукові записки Інституту політичних і етнонаціональних досліджень ім. І.Ф. Кураса НАН України, № $31,55$.

2 Фульмес, В. С. (2021). Церковно-релігійна і громадська діяльність митрополита Анатолія Дублянського: дисертація на здобуття наукового ступеня доктора філософії. Луцьк: Волинський національний університет, Україна, 94.

${ }^{3}$ Олійник, Ю. В. (2006). Преса Хмельниччини в роки окупації: становлення та діяльність (1941-1944рр.). Освіта, наука і культура на Поділлі: матеріали другого круглого столу (м. Кам янець-Подільський), 355.
} 
4. Ukrainskyi holos [Ukrainian Voice] (1943). Do chytachiv Proskurivskoi miskoi biblioteky, 21 liutoho [To the Readers of the Proskuriv City Library, February, 21], 4. [in Ukrainian].

5. Ukrainskyi holos [Ukrainian Voice] (1943). Do chytachiv Proskurivskoi miskoi biblioteky, 27 chervnia [To the Readers of the Proskuriv City Library, June, 27], 4. [in Ukrainian].

6. Ukrainskyi holos [Ukrainian Voice] (1941). Konkurs artystiv, 12 zhovtnia [Competition of Artist, October, 12 ], 6. [in Ukrainian].

7. Ukrainskyi holos [Ukrainian Voice] (1941). «Lymerivna» u postanovtsi miskoho dramatychnoho teatru, 3 hrudnia ["Lymerivna" is Staged by the City Drama Theater, December, 03], 4. [in Ukrainian].

8. Ukrainskyi holos [Ukrainian Voice] (1941). Lialkovyi teatr u Proskurovi, 27 chervnia [Puppet Theatre in Proskuriv, June, 27], 4. [in Ukrainian].

9. Ukrainskyi holos [Ukrainian Voice] (1941). Miska biblioteka, 23 lystopada [City Library, November, 23], 3. [in Ukrainian].

10. Ukrainskyi holos [Ukrainian Voice] (1941). Miskyi muzei, 30 veresnia [City Museum, September, 30], 4. [in Ukrainian].

11. Ukrainskyi holos [Ukrainian Voice] (1942). Narada v spravi miskoho teatru. [Meeting on the Case of the City Theater] (1942, 22 sichnia). Ukrainskyi holos [Ukrainian Voice], 4. [in Ukrainian].

12. Ukrainskyi holos [Ukrainian Voice] (1942). Oholoshennia, 8 lystopada [Advertising, November, 08], 4. [in Ukrainian].

13. Ukrainskyi holos [Ukrainian Voice] (1943). Oholoshennia, 21 zhovtnia [Advertising, October, 21 ], 4. [in Ukrainian].

14. Ukrainskyi holos [Ukrainian Voice] (1943). «Oi, ne khody, Hrytsiu, ta y na vechornytsi» (V postanovtsi Proskurivskoho dramatychnoho ukrainskoho teatru), 4 liutoho [“Oh, Hryts`, Don`t Go to Evening Parties" (Is Staged by the Proskuriv Drama Ukrainian Theater), February, 04], 4. [in Ukrainian].

15. Oliinyk, Yu. V. (2006). Presa Khmelnychchyny v roky okupatsii: stanovlennia ta diialnist (1941-1944 rr.) [The Press of Khmelnytsky Region During the Years of Occupation: Formation and Activity (1941-1944)]. Osvita, nauka i kultura na Podilli: materialy druhoho kruhloho stolu (m. Kam yanets-Podilskyi) [Education, science and culture in Podillya: materials of the second round table (Kamyanets-Podilskyi)], 354-359. [in Ukrainian].

16. Oliinyk, Yu., Zavalniuk, O. (2012). Natsystskyi okupatsiinyi rezhym v heneralnii okruzi «Volyn-Podillia» (1941-1944 rr.) [Nazi Occupation Regime in the General District "Volyn-Podilia (1941-1944)]. Khmelnytskyi: Polihrafist-2. [in Ukrainian].

17. Ukrainskyi holos [Ukrainian Voice] (1942). Persha rokovyna Proskurivskoho dramatychnoho teatru, 25 zhovtnia [The First Anniversary of the Proskuriv Drama Theater, October, 25], 4. [in Ukrainian].

18. Ukrainskyi holos [Ukrainian Voice] (1942). Proskurivskyi muzei antysovetskoi kultury, 23 lypnia [Proskuriv Museum of Anti-Soviet Culture, July, 23], 4. [in Ukrainian].

19. Ukrainskyi holos [Ukrainian Voice] (1942). Reorhanizatsiia miskoho teatru, 19 liutoho [Reorganization of the City Theater, February, 19], 4. [in Ukrainian].

20. Ukrainskyi holos [Ukrainian Voice] (1941). Tvorcha pratsia, 18 hrudnia [Creative work, December, 18 ], 4. [in Ukrainian].

21. Ukrainskyi holos [Ukrainian Voice] (1942). Teatralna khronika, 14 travnia [Theatrical Chronicle, May, 14], 4. [in Ukrainian].

22. Ukrainskyi holos [Ukrainian Voice] (1941). Vydannya vid, 25 sichnia [Edition, January, 25], 4. [in Ukrainian].

23. Ukrainskyi holos [Ukrainian Voice] (1942). Vydannya vid, 8 bereznia [Edition, March, 08], 4. [in Ukrainian].

24. Ukrainskyi holos [Ukrainian Voice] (1941). Ukrainskyi kontsert, 21 hrudnia [Ukrainian Concert, December, 21], 3. [in Ukrainian].

25. Fulmes, V. S. (2021). Tserkovno-relihiina i hromadska diialnist mytropolyta Anatoliia Dublianskoho [Church-Religious and Public Activity of Metropolitan Anatoly Dublyansky]. Lutsk: VNU im. Lesi Ukrainky. [in Ukrainian].

26. Ukrainskyi holos [Ukrainian Voice] (1943). «Charivna halosha»v postanovtsi Proskurivskoho lialkovoho teatru, 1 serpnia ["Magic Halosha" is Staged by the Proskuriv Puppet Theater, August, 01], 4. [in Ukrainian].

27. Chernov, B. (2006). Okupatsiina presa Raikhskomisariatu Ukraina: rozbudova i funktsionuvannia (1941-1943 rr.) [Occupation Press of the Reichskommissariat Ukraine: Development and Operation (1941-1943)]. Naukovi zapysky Instytutu politychnykh i etnonatsionalnykh doslidzhen im. I.F. Kurasa NAN Ukrainy [Scientific notes of the Institute of Political and Ethnonational Studies. IF Beauty of the National Academy of Sciences of Ukraine], 31, 51-68. [in Ukrainian]. 